\title{
Article 297 of the United Nations Convention on the Law of the Sea and the Scope of Mandatory Jurisdiction
}

(2017) 48(3) Ocean Development \& International Law (accepted unedited version)

\section{Stephen Allen*}

\section{Introduction}

This paper examines Article 297 of the UN Convention on the Law of the Sea $(\text { UNCLOS })^{1}$ and its drafting history in order to determine the way in which the scope of mandatory jurisdiction evolved during the process of drafting the Convention and how it has been interpreted subsequently by arbitral tribunals, legal practitioners and scholars. In so doing, this essay will show the difficulties that these constituencies have experienced in establishing the provision's meaning and the countervailing interpretations that have developed as a result. In particular, I will argue that the opposing interpretations of Article 297 reveal the contentious nature of the compulsory dispute resolution provisions contained in Part $\mathrm{XV}$ and the fragile commitment to the international rule of law, which characterised the Convention's development and has, thus far, informed its implementation.

Article 297 sets out the automatic exceptions to the compulsory procedures contained in section 2 of Part XV. The structure of Article 297 is somewhat convoluted. Notwithstanding its organisational shortcomings, it was widely thought that the thrust of the provision was clear - it seeks to limit the scope of mandatory jurisdiction in recognition of the authority of a coastal State to exercise its sovereign rights and

\footnotetext{
* Department of Law, Queen Mary, University of London. Email: s.r.allen@qmul.ac.uk. I would like to thank the organisers of the Access to Compulsory Binding Dispute Resolution under the Law of the Sea Convention Workshop for their invitation to participate in this event, which was hosted by the Jebsen Centre on 21 and 22 September 2016. I am grateful to Nigel Bankes for his very helpful comments and suggestions on a draft version of this essay.

110 December 1982, (1982) 21 ILM 1261, (1994) 1833 UNTS 3.
} 
jurisdiction in its extended maritime areas. ${ }^{2}$ However, the validity of this orthodox reading of Article 297 has been thrown into doubt as a result of Arbitral Tribunal's reasoning in the recent Chagos Award. ${ }^{3}$ In its Award, the Tribunal sought to harness various aspects of Part $\mathrm{XV}$ in order to extend the reach of compulsory procedures with regard to disputes involving the interpretation or application of the Convention.

In particular, it identified three ways in which Article 297 could be used to facilitate this aim. ${ }^{4}$ First, the Tribunal favoured a construction of Article 297(1) that was at odds with the way in which it had previously been interpreted by scholars and tribunals. This reading dramatically extends the scope for the exercise of mandatory jurisdiction in cases which were not expressly provided for in Article $297(1) .{ }^{5}$ Secondly, the Tribunal acknowledged the existence and potential effect of the inclusion of certain terms in Article 297 which provide renvoi to sources beyond the Convention. ${ }^{6}$ In this regard, it noted that Article 297(1)(a) refers to 'other internationally lawful uses of the sea specified in Article 58 of UNCLOS'. ${ }^{7}$ In addition, it observed that Article 297(1)(c) - which provides for compulsory jurisdiction in instances where it is claimed that a coastal State has contravened international norms for the protection and preservation of the marine environment in the extended maritime zones - permits reference not only to norms contained in the Convention but also to those rules and principles established by other international instruments. In the circumstances, the Tribunal

\footnotetext{
2 The meaning and effect of Article 297 has been addressed in a number of decisions since the 1982 Convention came into force. For instance, see the ITLOS Judgment in the M/V 'Saiga' (No 2) Case (Saint Vincent and Grenadines/Guinea)(1999) ITLOS Reports at 7; and the Southern Bluefin Tuna Case (New Zealand and Australia/Japan), Jurisdiction and Admissibility Award, 4 August 2000.

${ }^{3}$ Chagos Marine Protected Area (Mauritius v. United Kingdom) Award, 18 March 2015. More generally, see Stephen Allen, The Chagos Islanders and International Law (Hart 2014).

${ }^{4}$ See Stefan Talmon, 'The Chagos Marine Protected Area Arbitration: A Case Study of the Creeping Expansion of the Jurisdiction of UNCLOS Part XV Courts and Tribunals', 16 June 2016, Social Science Research Network: <http://ssrn.com/abstract=2796685> accessed 13 December 2016, 5.

${ }^{5}$ Chagos Award (n 3) [307-14] and [317].

6 ibid, [316].

7 And, in turn, Article 58(2) contains a renvoi referring to other pertinent rules of international law applicable in relation to the EEZ which are not incompatible with Part $\mathrm{V}$ of the Convention. See ibid.
} 
concluded that: 'Article 297(1) thus expressly expands the Tribunal's jurisdiction to certain disputes involving the contravention of legal instruments beyond the four corners of the Convention itself'. ${ }^{8}$ Finally, the Tribunal had to tackle the difficult task of characterizing the dispute in question for jurisdictional purposes. This responsibility required it to determine the intended, or prevailing effect, of the creation of the Chagos Archipelago/British Indian Ocean Territory Marine Protected Area. In essence, if Mauritius's challenge qualified as a dispute concerning the protection and preservation of the marine environment in accordance with Article 297(1)(c) then the Tribunal would have jurisdiction. However, if it was characterised as a fisheries dispute then the Tribunal would have to decline jurisdiction. This is because Article 297(3)(a) provides that a coastal State is not obligated to submit to section 2 procedures in the case of a dispute relating to the exercise of its sovereign rights in respect of those living resources located in its EEZ. Courts and tribunals are used to being confronted by such jurisdictional contests. Indeed, deciding the proper way to characterise a dispute is an everyday part of the judicial/arbitral function, notwithstanding the fact that it often requires judges and arbitrators to exercise considerable discretionary authority. ${ }^{9}$ However, the functional (or 'salami-slicing') approach to dispute settlement adopted in UNCLOS raises major questions regarding the justiciability of multi-faceted disputes. ${ }^{10}$ If overlapping claims cannot be divided and tailored then the denial of section 2 procedures in every case which exhibits an exclusionary aspect would signal the vanishing point of compulsory jurisdiction within the Convention's dispute settlement provisions.

\footnotetext{
8 ibid.

9 There was a similar contest the M/V Saiga (No.2) Judgment (n 2). The Applicant argued that jurisdiction arose by virtue of Article 297(1)(a) while the coastal State asserted that the claim was nonjusticiable because it amounted to a fisheries dispute that fell within the terms of Article 297(3)(a).

${ }^{10}$ See Alan Boyle, 'Dispute Settlement and the Law of the Sea Convention: Problems of Fragmentation and Jurisdiction', (1997) 46 ICLQ 37, 39.
} 
This paper does not deal with the significance of the renvoi to sources located outside of the Convention (this is covered by Kate Parlett's paper) nor with the issue of how disputes involving competing provisions of Article 297 are characterised (this is examined by James Harrison). Moreover, the way in which the Convention's provisions concerning the protection and preservation of the marine environment have evolved from broad framework principles into tangible and cogent procedural and substantive norms has already received considerable attention. ${ }^{11}$ Accordingly, this essay concentrates on the question of whether Article 297(1) has an exclusive or inclusive effect as far as the compulsory procedures in section 2 of Part $\mathrm{XV}$ are concerned. Different answers to this question would seem to have major ramifications for dispute settlement under Part XV and, potentially, for the international legal project more generally.

\section{The Origins of the Exclusionary Reading of Article 297(1)}

Articles 297, 298 and 299 together form section 3 of Part XV of UNCLOS. According to the title of section 3, these provisions constitute the 'Limitations and Exceptions to the Applicability of Section 2'. According to received wisdom, ${ }^{12}$ Article 297 sets out the general exceptions to the compulsory procedures contained in section 2 . The Article's heading reinforces this view: it states that the provision concerns the: 'Limitations on applicability of section 2'. This exclusionary aim appears to be supported by the precise terms of Article 297. It is worth setting out the terms of Article 297(1) at this point:

Article 297

Limitations on applicability of section 2

\footnotetext{
${ }^{11}$ For example, see Natalie Klein, Dispute Settlement in the UN Convention of the Law of the Sea (CUP 2005), [145-164].

12 See section 2.1 below.
} 
1. Disputes concerning the interpretation or application of this Convention with regard to the exercise by a coastal State of its sovereign rights or jurisdiction provided for in this Convention shall be subject to the procedures provided for in section 2 in the following cases:

(a) when it is alleged that a coastal State has acted in contravention of the provisions of this Convention in regard to the freedoms and rights of navigation, overflight or the laying of submarine cables and pipelines, or in regard to other internationally lawful uses of the sea specified in article 58;

(b) when it is alleged that a State in exercising the aforementioned freedoms, rights or uses has acted in contravention of this Convention or of laws or regulations adopted by the coastal State in conformity with this Convention and other rules of international law not incompatible with this Convention; or

(c) when it is alleged that a coastal State has acted in contravention of specified international rules and standards for the protection and preservation of the marine environment which are applicable to the coastal State and which have been established by this Convention or through a competent international organization or diplomatic conference in accordance with this Convention.

The chapeau to Article 297(1) provides that the compulsory procedures in section 2 'shall' be available in connection with a dispute concerning the interpretation or application of the Convention 'with regard to the exercise by a coastal State of its sovereign rights or jurisdiction' in a series of cases enumerated in sub-paragraphs (a)(c). Essentially, compulsory procedures are available in cases where it is claimed that: (a) a coastal State has contravened the High Seas freedoms/rights of third States in the extended maritime areas; or (b) where another State has done the same; or (c) where the coastal State has violated specific international norms concerning the protection and preservation of the marine environment in these zones.

\subsection{The Orthodox Reading of Article 297(1)}


It is notable that the chapeau to Article $297(1)$ is drafted in positive terms. ${ }^{13}$ Accordingly, it would appear that the provision anticipates the availability of compulsory jurisdiction in a concrete dispute if the terms of any of the three cases set out in Article 297(1)(a-c) are satisfied and as long as the general jurisdictional limitation contained in Article 288(1) is also met. As a result, it could be argued that the provision does not exclude or limit the applicability of section 2 procedures at all. However, such an assessment would require us to overlook the consequences of the positive formulation of the first paragraph. The key question here is what happens in cases other than those enumerated in sub-paragraphs $(a-c)$ ? Is a coastal State free from the obligation to submit to section 2 procedures in any other dispute involving the exercise of its sovereign rights or jurisdiction in its extended maritime areas? In other words, are all other disputes non-justiciable in the absence of a coastal State's willingness to consent to adjudication and arbitration in a specific case, pursuant to the terms of Article 299?

It was widely thought that, other than in the cases enumerated in Article 297(1)(a-c), a coastal State was immune from challenge with regard to the exercise of its sovereignty rights and jurisdiction, as far as section 2 of Part $\mathrm{XV}$ was concerned. As Lowe and Churchill observed: 'Article 297(1) provides that no dispute concerning the exercise by a coastal State of its sovereign rights or jurisdiction within its EEZ is subject to the "compulsory procedures entailing binding decision" set out in section 2 of Part XV of LOSC unless it is alleged [that the terms of one of the enumerated cases is satisfied]'. ${ }^{14}$ This interpretation also found favour with the Arbitral Tribunal in the Southern Bluefin Tuna Case. In its Award on Jurisdiction and Admissibility, the

\footnotetext{
13 See Klein (n 11), 141-2.

${ }^{14}$ Robin Churchill and Vaughan Lowe, The Law of the Sea (3rd edn, MUP 1999), 455, (emphasis added).
} 
Tribunal noted that Article 297 imposes 'significant limitations on the applicability of compulsory procedures insofar as coastal States are concerned'. ${ }^{15}$ It went on:

'Paragraph 1 of Article 297 limits the application of such procedures to disputes concerning the exercise by a coastal State of its sovereign rights or jurisdiction in certain identified cases only, i.e.: (a) cases involving rights of navigation, overflight, laying of submarine cables and pipelines or other internationally lawful uses of the sea associated therewith; and (b) cases involving the protection and preservation of the marine environment. ${ }^{16}$

These assessments of the text of Article 297(1) had the effect of implying an 'only' into the paragraph's chapeau so that a coastal State's exercise of its sovereign rights and jurisdiction in the extended maritime zones would only be subject to section 2 procedures in the enumerated cases. ${ }^{17}$ This reading of Article 297(1) has endured. Writing in 2015, Oxman fully endorsed it when he observed that: Article 297(1) 'establishes the basic rule generally limiting [...] challenges to the three situations enumerated in that paragraph $[\ldots]^{\prime} .{ }^{18}$

However, the authoritative interpretation of Article 297(1) has changed dramatically as a result of the construction favoured in the Chagos Award. It would be fair to say that its reading of Article 297(1) has had the effect of turning the orthodox position on its head. In outline, at this stage, the Tribunal reached the conclusion that not only did Article 297(1) confer mandatory jurisdiction in the three enumerated cases, thereby affirming jurisdiction in such situations, but that courts and tribunals retain compulsory jurisdiction pursuant to section 2 in all other cases, as long as a dispute concerns the interpretation or application of the Convention and the explicit

\footnotetext{
${ }^{15}$ Arbitral Tribunal in the Southern Bluefin Tuna Case (n 2), [61].

16 ibid.

17 Talmon (n 4), 21.

${ }^{18}$ Bernard Oxman, 'Courts and Tribunals: The ICJ, ITLOS and Arbitral Tribunals' in Donald Rothwell, in Alex Oude-Elferink, Karen Scott and Tim Stephens (eds), The Oxford Handbook of the Law of the Sea (OUP 2015) 394, 404.
} 
automatic restrictions on jurisdiction contain in Article 297(2) or (3) are not engaged. ${ }^{19}$ How could such an interpretative volte face have happened?

\subsection{The Special Character of Section 2 Compulsory Procedures}

\subsubsection{Structural and Literal Perspectives}

Section 1 of Part XV bases the Convention's provisions on dispute resolution on the principle of the peaceful settlement of disputes and it entrenches the traditional means of inter-State dispute settlement - with its emphasis on choice of settlement technique and the use of ad hoc consensual methods - in order to resolve specific disputes as and when they may arise. However, section 2 of Part XV establishes the principle of compulsory dispute settlement. It provides that this novel method will be applicable in relation to disputes concerning the interpretation and application of the Convention in certain situations. ${ }^{20}$ Finally, section 3 - which contains the automatic exceptions (Article 297) and the optional exceptions (Article 298) - purports to restrict the applicability of the radical principle of compulsory settlement in particular situations, thereby excluding certain cases from the reach of Part XV courts and tribunals.

Against this background, one plausible reading of the structure of Part $\mathrm{XV}$ is that section 2 provides the exception to the general principle, contained in section 1 , of ad hoc dispute settlement by means of adjudication or arbitration, while section 3 provides the exceptions to the exception. On first impressions, it would appear that the orthodox interpretation of Article 297(1) makes sense by reference to the basic structure of Part XV. Its structure seems to ensure that the traditional methods of inter-

\footnotetext{
${ }^{19}$ Chagos Award ( $n$ 3), [317]. Jurisdiction could also be ousted as a result of the making of an optional exclusion, under Article 298, in certain situations.

20 It is worth acknowledging that while section 2 provides for compulsory procedures in such exceptional cases the obligation to submit to such procedures is still rooted in State consent as State parties accept the terms of Part XV at the point of ratification. Some commentators prefer the term 'advanced consent', eg see Oxman (n 18), 397.
} 
State dispute settlement have priority over compulsory procedures, which are only available in a narrow range of cases. The exceptional nature of mandatory procedures, under section 2 , is reinforced by the additional exemptions to compulsory settlement, contained in section 3. Moreover, the title to section 3 and the caption to Article 297 support a restrictive reading of the availability of section 2 procedures.

Further, prima facie, a literal construction of the terms of Article 297(1) would seem to confirm the paragraph's exclusionary character. In essence, the provision reflects the balance of rights between Flag States and coastal States in the extended maritime areas. On the one hand, it endeavours to protect the High Seas freedoms/rights of Flag States and the marine environment by recognizing the applicability of international norms in such zones. But, on the other hand, it seeks to protect the sovereign rights and jurisdiction of coastal States in such places. The Convention's drafting history shows that negotiations concerning these competing sets of rights were very difficult and whether an acceptable balance between the entitlements, obligations and interests of maritime States and coastal States was achieved depends on one's perspective. Flag States were anxious to ensure that their Article 87 freedoms were respected and that the means to challenge alleged interferences with these rights in the extended maritime zones was assured by guaranteeing the availability of mandatory jurisdiction in such situations. In contrast, coastal States were eager to entrench their freedom to exploit and control their natural resources and to exercise exclusive jurisdiction as far as possible within their EEZs and on their continental shelves. ${ }^{21}$

\footnotetext{
${ }^{21}$ See John Noyes, 'Compulsory Third Party Adjudication and the 1982 United Nations Convention on the Law of the Sea' (1989) 4 Connecticut Journal of International Law 675, 686-7.
} 
It might be claimed that a construction of Article 297(1) based on the ordinary meaning of the words used in that paragraph - in accordance with the terms of Article 31(1) of the Vienna Convention on the Law of Treaties ${ }^{22}$ (VCLT) - would seem to suggest that mandatory jurisdiction is, in fact, only triggered in the three enumerated cases. $^{23}$ The paragraph's chapeau provides that section 2 procedures 'shall' be applicable 'in the following cases'. Thus, beyond the situations enumerated in Article 297(1)(a-c), a coastal State, exercising its sovereign rights and jurisdiction in the extended maritime areas, is under no obligation to submit to section 2 procedures. It may be assumed that the Convention's drafters were fully aware of the consequences of the paragraph's positive formulation and that this understanding was accurately reflected in the text. The corollary of this particular reading is that sovereign rights and jurisdiction in all other cases have been attributed to the responsible coastal State and that the exercise of its entitlements and authority is immune from challenge via the procedures set out in section $2 .{ }^{24}$ Thus, it could be argued that the three key elements - the basic structure of Part XV, the title to section 3, the caption to Article 297 and the ordinary meaning of the text of Article $297(1)$ - all point in the same direction: mandatory jurisdiction does not exist outside of the three cases enumerated in that paragraph.

\subsubsection{Broad Conceptions of Mandatory Jurisdiction}

\footnotetext{
2223 May 1969, (1969) 8 ILM 679, (1980) 1155 UNTS 331.

${ }^{23}$ Article 31(1) VCLT provides that: A treaty shall be interpreted in good faith in accordance with the ordinary meaning to be given to the terms of the treaty in their context and in the light of its object and purpose'.

${ }^{24}$ This does not involve a situation where rights and jurisdiction have not been attributed by the Convention which would then permit recourse to the broad principles of equity, in accordance with Article 59 UNCLOS.
} 
However, other interpretations are also plausible. ${ }^{25}$ From the earliest sessions of the Third Conference there was considerable support, from participating States, for the principle of compulsory dispute settlement. Delegates understood that the nature of the entitlements and obligations contained in the draft Convention and the way in which its terms were negotiated had major ramifications for the Convention's provisions concerning dispute settlement. The need to establish a radical approach to dispute settlement as a way of protecting the integrity of the rights and obligations enshrined in the Convention and to stabilise this new legal order for the seas was appreciated from a very early stage. For instance, during the 1974 Caracas session, the four aims for the Convention's dispute settlement provisions were proclaimed, namely that: (1) the parties were committed to the principle of settling their dispute by recourse to legal rather than political means, thereby seeking to prioritize the Rule of Law over real-politik considerations; (2) that the use of compulsory dispute resolution procedures would bring about a high degree of uniformity regarding the interpretation of the Convention's provisions; (3) the drafters aspired to ensure that any exceptions to the principle of compulsory dispute settlement would be carefully delimited so as to promote the obligatory character of the Convention's dispute settlement provisions; and (4) the negotiating parties were committed to ensuring that the dispute settlement provisions would form an integral part of the Convention as a whole. ${ }^{26}$ These aims guided the subsequent drafting sessions and the First President's 1976 observation, that the dispute settlement procedures must provide the pivot required to maintain the

\footnotetext{
${ }^{25}$ For example, see Justice Keith's vigorous dissent in his Separate Opinion to the 2000 Southern BlueFin Tuna Award (n 2) especially [21-32].

${ }^{26}$ These broad aims were articulated by Ambassador Galindo Pohl (El Salvador). See S Rosenne and L B Sohn (eds), The United Nations Convention on the Law of the Sea 1982: A Commentary, Vol. V ('the Virginia Commentary') (Brill 1989), [297.2].
} 
delicate equilibrium of the compromises that underpinned the Convention, ${ }^{27}$ echoed throughout the various stages of the Convention's development.

These ideas have shaped the interpretation and application of the Convention ever since, albeit with varying degrees of success. Given: (i) the exceptional way in which the Convention was negotiated, with its informal methods and by the extensive use of package deals; (ii) the impermissibility of reservations; (iii) the existence of a commitment to only allow for a narrow range of substantive exceptions to the Convention; and, (iv) the extent to which certain key substantive and procedural rights and obligations were broadly conceived or programmatic in nature, it was clear that the drafters appreciated the important role that Part XV, and compulsory jurisdiction in particular, would play in implementing the Convention's provisions. Seen from this perspective, there are good grounds for believing that the drafters considered the applicability of mandatory jurisdiction to be far from exceptional. In the circumstances, it is arguable that the orthodox reading of Article 297(1) was vulnerable to challenge right from the start. Consequently, rather than prioritizing the traditional modes of dispute resolution (acknowledged in section 1 of Part $X V$ ) at the expense of the compulsory procedures established in section 2 (with the assistance of the exceptions contained in section 3 ) it is possible to invert the relationship between the two approaches to dispute resolution. To this end, it is conceivable that mandatory jurisdiction should be given precedence in cases where compulsory procedures are warranted under the Convention's dispute settlement provisions. The resonance of the lex specialis interpretative device is plausible in such a situation. Accordingly, it may well be that the principle that the parties retain the freedom to resolve their dispute by any peaceful means of their own choosing constitutes the general norm while the

${ }^{27}$ UN Doc A/CONF 62/WP 9/Add I, 31 March 1976, [6]. 
principle of compulsory dispute settlement represents the special law which is applicable in exceptional cases. ${ }^{28}$

But despite the appeal of expansive interpretations of compulsory jurisdiction, a note of caution should be sounded at this point. It is important to ask whether the aspirations that guided the drafters in the early sessions of the Third Conference were reflected in the final text of the Convention or did they end up being negotiated away. ${ }^{29}$ If the latter is true then there is a danger of attributing too much weight to the views that, with hindsight, overstated the radical character of the Convention's dispute settlement provisions and underestimated the old habits of international dispute resolution. In this context, Adede observed that, in the latter stages of the drafting process, negotiating States began to retreat from their commitment to mandatory jurisdiction. This was especially noticeable in relation to the exceptions identified in draft versions of what became Article 297(2) and (3) where, in specific cases, the compulsory jurisdiction of Part XV courts and tribunals was replaced by processes of compulsory conciliation, pursuant to Annex 5 of the Convention, which did not result in binding decision. Overall, Adede indicated that the final text of Part XV was a 'great disappointment' to the proponents of a dispute settlement system that would embody a strong commitment to mandatory jurisdiction. ${ }^{30}$ The key question is how should we interpret the terms of Part XV now and, in particular, given the scope of this paper, the relationship between sections 2 and 3 of Part XV through the lens of Article 297?

\footnotetext{
28 The full implications of the lex specialis interpretative device were explored by the International Law Commission in its 'Report on the Fragmentation of International Law' 13 April, 2006. UN DOC A/CN4/L 682, particularly [56-122].

${ }^{29}$ Klein appreciates this issue but she attributes the drafters' 'selective' approach to the scope and content of compulsory dispute settlement - i.e. the gap between the early aspirations and the complexities and qualifications of the final text - to a conscious, careful and concerted effort to deliver the best possible outcome in keeping with the political realities in existence at the time of the Third Conference, $\mathrm{n} 11,28$. However, this generous assessment underplays the extent to which the drafting process was driven by difficult and incremental political compromises rather than principled consensus. ${ }^{30}$ A O Adede, The System for Settlement of Disputes Under the United Nations Convention of the Law of the Sea (Brill 1987), 242.
} 


\section{The Chagos Tribunal's Assessment of Article 297}

\subsection{The Tribunal's Textual Construction of Article 297(1)}

The Tribunal examined the text of Article 297(1) in an effort to interpret its terms in accordance with the canons of construction contained in Article 31(1) of the VCLT. To this end, it made two preliminary observations regarding the apparent exclusionary character of the provision. First, it noted that, despite its title, Article 297 actually affirms the applicability of compulsory jurisdiction in the three enumerated cases. Moreover, it observed that the provision does not expressly restrict a tribunal's jurisdiction in any other cases so long as the general jurisdictional requirement contained in Article 288(1) is satisfied. ${ }^{31}$ Secondly, as 297(2) and (3) acknowledge, in principle, section 2 procedures are available with regard to the conduct of maritime scientific research and fisheries disputes respectively (subject to certain explicit limitations) the Tribunal concluded that jurisdiction, pursuant to section 2, could not be restricted to the three cases established in Article $297(1)(a-c) .{ }^{32}$ It ruled that if such a construction was justified (i.e. if an 'only' could be implied into the paragraph's chapeau, as the orthodox position suggests) then there would be no need to set out the principle of mandatory jurisdiction, and the exceptions to it, in Article 297(2) and (3) respectively. ${ }^{33}$

If the Tribunal had been starting with a clean slate it may have decided, on a straightforward textual construction, that section 2 procedures were not restricted by the terms of Article 297, beyond the limitations to jurisdiction set out in 297(2) and (3). However, mindful of the orthodox interpretation of Article 297(1), the Tribunal seems

\footnotetext{
${ }^{31}$ Chagos Award (n 3), [307].

32 ibid.

33 ibid, [308].
} 
to have adopted the preliminary view that the text's meaning was provisionally indeterminate. To this end, it noted that the intention behind the text of Article 297(1) 'remains far from clear'. ${ }^{34}$ This lack of clarity justified a close examination of the drafting history of the provision in an attempt to divine the provision's true meaning.

\subsection{The Tribunal's Examination of the Drafting History to Article 297}

\subsubsection{The Express/Implied 'Only' and the Effect of the 'Catch-all' Paragraph}

In this context of this investigation, the Tribunal pointed out that the 1976 version of Article 17 of the Revised Single Negotiating Text (RSNT), the precursor to Article 297, did expressly limit mandatory jurisdiction to a series of cases enumerated in the first paragraph. The chapeau to the first paragraph of this draft Article stated that: 'the exercise by a coastal State of sovereign rights, exclusive rights or exclusive jurisdiction recognized by the present Convention shall be subject to procedures in specified in section 2 only in the following cases'. It is worth setting out the text of this draft Article at this stage:

Article 17, Revised Single Negotiating Text (23 November 1976)

1. Disputes relating to the exercise by a coastal State of sovereign rights, exclusive rights or exclusive jurisdiction recognized by the present Convention shall be subject to the procedures specified in section 2 only in the following cases:

a) When it is claimed that a coastal State has acted in contravention of the provisions of the present Convention in regard to the freedom of navigation or overflight or of the laying of submarine cables and pipelines and other internationally lawful uses of the sea related to navigation or communication; or

b) When it is claimed that any State, in exercising the aforementioned freedoms, has acted in contravention of the provisions of the present Convention or of laws or regulations enacted by the coastal State in

34 ibid, [314]. 
conformity with the present Convention and other rules of international law not incompatible with the present Convention; or

c) When it is claimed that a coastal State has acted in contravention of specified international standards or criteria for the preservation of the marine environment or for the conduct of marine scientific research, which are applicable to the coastal State and which have been established by the present Convention or by a competent international authority acting in accordance with the present Convention; or

d) When it is claimed that a coastal State has manifestly failed to comply with specified conditions established by the present Convention relating to the exercise of its rights or performance of its duties in respect of living resources, provided that in no case shall the sovereign rights of the coastal State be called in question. ${ }^{35}$

Notwithstanding their rudimentary formulation, the cases enumerated in the first paragraph were, very broadly, the same as those contained in the final version of Article 297, save for the inclusion of a fourth case in the 1976 draft (concerning situations where a coastal State has manifestly failed to comply with its rights and duties over living resources in the EEZ). Accordingly, in the 1976 version, section 2 procedures were not available outside of the four identified cases. This literal construction of the draft text was reinforced by paragraph 2 of draft Article 17, which provided that: 'Any dispute excluded by paragraph 1 may be submitted to the procedure specified in section 2 only with the express consent of the coastal State concerned'. The meaning of the 1976 version was absolutely clear and it accords with the orthodox interpretation of the final provision - compulsory jurisdiction was excluded in all cases not specifically identified in paragraph 1, unless a coastal State was prepared to consent to adjudication or arbitration in relation to a given dispute.

\footnotetext{
${ }^{35}$ Official Records of the Third United Nations Conference on the Law of the Sea, Volume VI (Summary Records, Plenary, General Committee, First, Second and Third Committees, as well as Documents of the Conference, Fifth Session), Revised Single Negotiating Text, Part IV, Art 17, UN Doc A/CONF 62/WP 9/Rev 2 (23 November 1976).
} 
However, tracking the evolution of this provision, the Tribunal observed that the content of subsequent draft versions changed substantially as new terms were added. In its view, such developments had the effect of dramatically changing the meaning of the draft text. In particular, major changes were introduced, in the 1977 and 1979 versions, in order to give effect to the concerns of maritime States, who were anxious to ensure that compulsory jurisdiction was available in order to protect their High Seas freedoms from the prospect of the unchecked exercise of sovereign rights and jurisdiction by coastal States in the extended maritime zones. In contrast, coastal States were troubled by the possible abuse of compulsory procedures by powerful maritime States to such an extent that their newly-acquired sovereign rights and jurisdiction would be undermined. ${ }^{36}$ In the spirit of compromise, draft provisions designed to filter out vexatious and/or frivolous claims against coastal States were included in the 1977 draft. ${ }^{37}$ But, in order to accommodate the concerns of maritime States, the principle of mandatory jurisdiction was extended to the conduct of marine scientific research by third States in the EEZ and on the continental shelf (paragraph 3) and to certain disputes regarding the control and exploitation of living resources in the EEZ (paragraph 4), subject to express limitations in both cases. ${ }^{38}$

The structure of the draft Article altered as a result of these additions. The new preliminary filters were inserted into paragraph 1 so that compulsory procedures would 'only' be available when a tribunal has established: that the claim is, prima facie, well founded ((1)(a)); that it does not amount to an abuse of process or is frivolous or vexatious in nature $((1)(b))$; and that the coastal State in question has been notified

\footnotetext{
${ }^{36}$ See the Virginia Commentary (n 26), [297.6].

37 ibid, [297.11].

38 ibid, [297.11-12].
} 
and has been afforded the right to make objections ((1)(c)). Specifically, the draft Article in the 1977 version provided that:

\section{Draft Article 296 [297] Informal Composite Negotiating Text (15 July 1977)}

1. Without prejudice to the obligations arising under section 1 , disputes relating to the exercise by a coastal State of sovereign rights or jurisdiction provided for in the present Convention shall only be subject to the procedures specified in the present Convention when the following conditions have been complied with:

(a) that in any dispute to which the provisions of this article apply, the court or tribunal shall not call upon the other party or parties to respond until the party which has submitted the dispute has established prima facie that the claim is well founded;

(b) that such court or tribunal shall not entertain any application which in its opinion constitutes an abuse of legal process or is frivolous or vexatious; and

(c) that such court or tribunal shall immediately notify the other party to the dispute that the dispute has been submitted and such party shall be entitled, if it so desires, to present objections to the entertainment of the application.

2. Subject to the fulfilment of the conditions specified in paragraph 1 , such court or tribunal shall have jurisdiction to deal with the following cases [...]'.

5. Any dispute excluded by the previous paragraphs may be submitted to the procedures specified in section 2 only by the agreement of the parties to such a dispute. ${ }^{39}$

As a result, in the 1977 version, the specific cases where mandatory jurisdiction was available were moved to paragraph 2. But not only was the fourth case - concerning a coastal State's responsibilities with regard to the management and control over living resources in the EEZ - moved to paragraph 4, the qualification that had restricted compulsory jurisdiction to only those cases identified in the first paragraph of the 1976

\footnotetext{
39 Official Records of the Third United Nations Conference on the Law of the Sea, Volume VIII (Informal Composite Negotiating Text, Sixth Session), Informal Composite Negotiating Text, Art 296, UN Doc A/CONF 62/WP 10 (15 July 1977).
} 
version was excised from the corresponding part of the 1977 draft. Consequently, it would appear as though a more extensive interpretation of mandatory jurisdiction was possible from the 1977 draft onwards.

However, the Chagos Tribunal did not share this reading of the effect of the changes introduced in the 1977 draft. $^{40}$ It decided that the exclusionary character of the draft provision was maintained by the 'catch all' device included in paragraph 5, which was essentially replicated in paragraph 4 of the 1979 draft. It provided that: 'Any dispute excluded by the previous paragraphs may be submitted to the procedures specified in section 2 only by the agreement of the parties to such a dispute'. ${ }^{41}$ This reading of the effect of this paragraph is open to question. I would argue that paragraph 5 permits recourse to section 2 procedures by the consent of the parties to a dispute in cases which would otherwise be expressly excluded by paragraphs 1, 3 or 4 of the draft Article. Paragraph 5 was designed to bring those cases that were specifically excluded from compulsory jurisdiction within the purview of section 2 procedures. ${ }^{42}$ As a result, it is suggested that paragraph 5 of the 1977 draft (and paragraph 4 of the 1979 version) do not have an overriding exclusionary character, they simply give effect to the uncontroversial tenet that the parties can always agree to confer jurisdiction in a specific case.

The material paragraph was removed from draft Article 297 in the 1980 version and a revised formulation was inserted into Article 299(1). ${ }^{43}$ The Virginia Commentary

\footnotetext{
40 Chagos Award (n 3), [314].

${ }^{41}$ Official Records of the Third United Nations Conference on the Law of the Sea, Volume VIII (Informal Composite Negotiating Text, Sixth Session), Informal Composite Negotiating Text Revision 1, Art. 296, UN Doc A/CONF 62/WP 10/Rev 1 (28 April 1979).

42 Essentially those anticipated by paragraph 3 (the express limitations to scientific research activities in the extended maritime zones); and paragraph 4 (especially the exception concerning a coastal State's sovereign rights over regarding living resources located in the EEZ).

43 Official Records of the Third United Nations Conference on the Law of the Sea, Volume VIII (Informal Composite Negotiating Text, Sixth Session), Informal Composite Negotiating Text Revision 3, Art 297, UN Doc A/CONF 62/WP 10/Rev 3 (22 September 1980). Article 299(1) provides: 'A dispute excluded under article 297 or excepted by a declaration made under article 298 from the dispute settlement
} 
confirms that the initial idea behind the 'jurisdiction by consent' formula, contained in paragraph 2 of the 1976 version, was to reinforce the exclusionary nature of paragraph 1 of that draft provision. ${ }^{44}$ However, the Commentary acknowledges that the special consent provision was reformulated in the 1977 version. ${ }^{45}$ It alludes to the negative aspect of final Article 299(1) by reminding us that a dispute which is excluded from mandatory jurisdiction by the terms of Article 297 cannot be the subject of section 2 procedures by unilateral application. ${ }^{46}$ However, I would suggest that the negative aspect is only triggered where a case has been expressly excluded from the scope of mandatory jurisdiction rather than being excluded by default. The Commentary also recognises the positive effect of Article 299(1) by reaffirming the right of parties to submit a dispute to the dispute settlement procedures provided for in section 2 whenever they are able to reach agreement on the modalities of such submissions'. ${ }^{47}$

It is suggested that the effect of revising the first paragraph of the 1976 version for the purpose of inclusion in paragraph 2 of the 1977 version (i.e. excising the 'only' in the chapeau which had restricted mandatory jurisdiction to the enumerated situations) was to widen the availability of the section 2 procedures in cases concerning the interpretation or application of the Convention. Without this key restriction the supposed 'catch all' exclusionary paragraph contained in the 1977 and 1979 versions was without effect (unless a situation had been expressly excluded from the compulsory procedures identified in section 2 in accordance with the explicit limitations contained in Article 297). The Chagos Tribunal did not seem to appreciate that this special consent paragraph was subsequently incorporated into Article 299 but

procedures provided for in section 2 may be submitted to such procedures only by agreement of the parties to the dispute'.

${ }^{44}$ The Virginia Commentary, (n 26), [299.2].

45 ibid, [299.3].

46 ibid, [299.5].

47 ibid. 
it did acknowledge the fact of its disappearance meant that, by the time the text of the Convention had been finalized, there were no general restrictions on the availability of section 2 procedures included in Article 297 (beyond those explicit limitations included in Article 297(2) and (3)). Accordingly, in general, as long as the jurisdictional restrictions in Article 288 were satisfied then compulsory jurisdiction would be available.

Nonetheless, in reaching its conclusion that the terms of Article 297(1) did not impose any jurisdictional restrictions on courts and tribunals by default, the Chagos Tribunal referred to the Virginia Commentary for an explanation of the changes in the draft text between 1976 and 1980 and, in particular, the omission of the qualifying 'only' from the chapeau of the first paragraph in the final text of Article 297. Relying upon the Commentary, the Tribunal observed that: 'the change was linked to the addition of express limitations for fisheries and marine scientific research'. ${ }^{48}$ However, it is evident that the Commentary was more equivocal in this respect. It stated that this omission: 'was probably due to the fact that additional recourse to third-party dispute settlement procedures was provided in other paragraphs of the article'. ${ }^{49}$ It is suggested that in its Award, the Chagos Tribunal glossed over the deep divisions that persisted, between the negotiating parties, as to the precise terms of Article 297 during the last stage of the Convention's finalization.

\subsubsection{The Late Push for Adjustments to Article 297}

Participating States agreed to certain alterations, recommended by Negotiating Group 5, during the 1978 drafting session, in an attempt to resolve the controversy

\footnotetext{
${ }^{48}$ Chagos Award (n 3), [314].

49 Virginia Commentary (n 26), [297.18].
} 
surrounding the scope of compulsory settlement procedures. However, there is no doubt that the 1979 draft amounted to a reluctant compromise. ${ }^{50}$ Maritime States were unhappy about the hollowing out of the principle of mandatory jurisdiction while coastal States were still not satisfied by the limitations placed on their sovereign rights and jurisdiction by the draft Article. And even though further adjustments were made to subsequent iterations of the draft text, it is fair to say that no-one was truly happy with the terms of Article 297 as the Convention was being finalized. Indeed, as late as August 1980, negotiating States were still trying to make substantive changes to the text of Articles 297 and 298 in an effort to rebalance the provision in ways that would best protect their own rights and interests. The President resisted such efforts at the informal plenary meeting of the Conference during the resumed Ninth Session, in August 1980. He argued that the existing version of the draft text had already been the subject of very careful negotiations and was the product of delicate compromises that could not be reopened at such a late stage. ${ }^{51}$ Of course, it is not open to us to dispute the actual terms of the Convention's final text. Nevertheless, the late battles regarding the content of Article 297 do make it difficult for us to discern the overriding intentions of the parties by reference to draft versions of the Convention.

\subsection{The Enduring Appeal of the Orthodox View}

At one level, it is hard to be sure of the correctness of the Chagos Award's assessment of the drafting history behind Article 297. In the absence of a comprehensive historical record of the drafting sessions it is difficult to know for certain why the qualifying 'only'

\footnotetext{
${ }^{50}$ Eg see Adede (n 30), 165-175.

51 Official Records of the Third United Nations Conference on the Law of the Sea, Volume XIV (Summary Records, Plenary, General Committee, First and Third Committees, as well as Documents of the Conference, Resumed Ninth Session (28 July to 29 August 1980)), Report of the President on the work of the informal plenary meeting of the Conference on the settlement of disputes, UN Doc A/CONF 62/L 59 (23 August 1980).
} 
was omitted from the 1977 version and from all subsequent versions. It may have been the consequence of the disruptive effect of inserting the paragraph providing for the preliminary filters which were then subsequently relocated elsewhere. The omission might have been an oversight, or due to poor drafting, rather being attributable to a conscious decision resulting from attempts to strike of a balance between the rights and interests of coastal and maritime States. Accordingly, despite the interpretation favoured in the Chagos Award, it is still possible to find support for the orthodox reading of Article 297(1) in the draft versions of the Convention.

In essence, in the 1976 draft, the availability of mandatory jurisdiction in connection with a coastal State's exercise of its sovereign rights and jurisdiction in the extended zones, was affirmed, in paragraph 1(a-d), in relation to: the exercise of High Seas freedoms; the protection of the maritime environment in accordance with international standards; and the management of living resources (subject to a broad exemptions). Compulsory procedures were positively excluded in all other situations and this was reinforced in paragraph 2 of the 1976 draft. Subsequent draft versions elaborated the availability of mandatory procedures in relation to the control and exploitation of living resources in the EEZ while adding that section 2 procedures would be available, in principle, concerning scientific research activities in the extended zones.

Against this background, the argument in favour of the orthodox view is that, in the later drafts, compulsory jurisdiction was still broadly anticipated in the four cases which had been enumerated in paragraph 1 of the 1976 version. However, the subsequent versions reorganised the four enumerated cases so that they were included in different paragraphs of the draft Article (with scientific research being added as a fifth distinct such case from 1977 onwards) as the drafters revised and 
refined the instances in which mandatory jurisdiction would arise. Therefore, on one plausible reading, the thrust of the draft Article remained the same throughout the entire exercise: it aimed to establish the situations when the compulsory procedures could be triggered. It is arguable that what was explicit in the 1976 draft was assumed by the drafters in subsequent versions thereafter. Consequently, on this interpretation of Article 297, compulsory jurisdiction would only arise in the extended zones, in response to claims made against a coastal State in the following cases: (i) in relation to the exercise of High Seas freedoms (Article 297(1)(a)); (ii) where international norms concerning the protection and preservation of the marine environment have been contravened (Article 297(1)(c)); (iii) regarding scientific research activities (Article 297(2), subject to restrictions); and (iv) in respect of the control or exploitation of living resources in the EZZ (Article 297(3), subject to broad exceptions). This interpretation of the scope of section 2 procedures extends beyond the act of implying an 'only' into the chapeau to Article 297(1) as it involves an assessment of the meaning and effect of the terms of Article 297 as a whole. Nevertheless, it is at least consistent with the tenor of the orthodox interpretation of Article 297(1).

In the circumstances, it would appear as though the two contrasting interpretations of Article 297 - the orthodoxy holding that compulsory jurisdiction arises only in the cases enumerated in Article 297(1),(2) and (3) (subject to the explicit exceptions) and the position favoured in the Chagos Award (that mandatory jurisdiction arises in all cases involving the interpretation or application of the Convention which have not been expressly excluded by Article 297) - are irreconcilable by reference to an assessment of both the Convention's final text and its draft versions. It seems to me that the only plausible way forward in such a situation 
is to see if legal theory can help us to find a reliable route around this doctrinal impasse.

\section{The Sematic Authority of Courts and Tribunals}

Venzke embraces the 'linguistic turn' which holds that the meaning of words is determined by their practical use. ${ }^{52} \mathrm{He}$ argues that, in the international legal context, the struggle to divine meaning from a given text cannot be fully resolved by the application of the rules of interpretation set out in Article $31(1)$ of the VCLT. ${ }^{53}$ Establishing the parties' intentions by reference to the ordinary meaning of the words used in a particular environment, or by looking behind them to the purposes which they are designed to serve, is problematic because any resulting construction remains contestable. ${ }^{54}$ One way out of this difficulty is to study the drafting history of a particular text in a bid to determine, or confirm, its meaning and this was the course of action followed by the Tribunal in the Chagos Award.

Article 32 of the VCLT permits recourse to a treaty's preparatory materials in hard cases and, in particular, where the application of Article 31(1) leaves things ambiguous or obscure. ${ }^{55}$ However, Venzke points out that the value of this interpretative approach is questionable in many cases for a number of reasons. First, it presupposes that the intentions of the drafters were clear during the drafting process. Secondly, the historical record concerning a text's development may not be sufficiently complete or accurate so as to act as a reliable guide to the intentions of the negotiating

\footnotetext{
52 Ingo Venzke, How Interpretation Makes International Law: On Sematic Change and Normative Twists (OUP 2012), 27-30.

53 ibid, 1-2.

54 ibid, 2.

${ }^{55}$ Article 32 VCLT provides: 'Recourse may be had to supplementary means of interpretation, including the preparatory work of the treaty and the circumstances of its conclusion, in order to confirm the meaning resulting from the application of article 31 , or to determine the meaning when the interpretation according to article 31: (a) leaves the meaning ambiguous or obscure; or (b) leads to a result which is manifestly absurd or unreasonable'.
} 
parties. Thirdly, privileging the preparatory materials in a search for meaning is an inherently backward-looking exercise which may reflect a particular political dynamic that is no longer relevant at the time the act of interpretation takes place. Fourthly, the drafters will not have foreseen and/or provided for every future contingency and so the draft materials may be of limited value in the light of subsequent events. Finally, draft versions are texts that are vulnerable to the ordinary challenges of interpretation and their significance may not be easily accessible to contemporary interpreters as a result. ${ }^{56}$

General concerns about the value of preparatory materials are heightened in the context of the development of UNCLOS. As it is well known, the negotiating States decided to adopt an informal approach to the drafting of the Convention. In part, this method was prompted by the way in which the Convention evolved, namely by the adoption of an informal approach to negotiations and the extensive use of packagedeals in the proclaimed spirit of compromise. The successive versions of the draft Convention are available to show us how the text developed at various stages during the negotiating process. However, we do not have a comprehensive and authoritative record of the debates that informed these draft versions of the Convention. In short, there is no travaux available to reveal the real intentions that lay behind particular provisions of the final version of the Convention.

But Venzke's broad theoretical insights offer us a way forward here. He argues that texts experience changes in their meaning, not only during the drafting stage but also after their finalisation. It is widely recognised that treaties are living instruments and debates about the meaning of their provisions endure. Venzke claims that courts and tribunals bear the (final) burden of completing the law-making process through the

56 Venzke (n 52), 3-4. 
production of authoritative interpretations in concrete cases. ${ }^{57}$ These decisions, in turn, become key reference points - along with the texts in question - for the purpose of guiding lawyers in the development of plausible legal arguments. In this respect, as Venzke tells us, judges and arbitrators do not simply discover the law but rather, through discrete acts of interpretation, they contribute to what they find. ${ }^{58}$ The significance of textual constructions favoured by courts and tribunals at the international level is enhanced by the absence of a centralised legislative process, which could be used to correct problematic interpretations of extant legal instruments. Venzke argues that this fact of international life increases the interpretative or sematic authority of international judicial and arbitral institutions. It is suggested that the drafters of UNCLOS fully anticipated this important aspect of the work of courts and tribunals and this appreciation explains the preoccupation of key actors with the task of developing cogent dispute settlement provisions in draft Convention. In particular, it was recognised that the availability of the compulsory procedures would maintain the integrity of the Convention as a whole thus enabling it to respond effectively to the changing needs of international community as time went by.

Against this background, it is arguable that the indeterminacy surrounding the correct interpretation of the scope of Article 297(1) - whether it affirms broad mandatory jurisdiction or whether it excludes it - is not capable of being resolved by recourse to the final text or any draft version of it. Instead, as Venzke claims, this obsession with the text must eschewed in recognition of the critical role performed by courts and tribunals and the way in which they exercise their semantic authority in a

\footnotetext{
57 ibid, 4.

58 ibid, 4. This point was acknowledged, in cases of maritime delimitation, by the Arbitral Panel in the Bay of Bengal Maritime Boundary Arbitration Award (Bangladesh/India), 7 July 2014, when it observed that the findings of courts and tribunals in this area constitute an acquis judiciaire which should be read into the text of Article 74 and 83 of UNCLOS ([339]).
} 
bid to establish legitimate interpretations in situations where contested meanings arise. ${ }^{59}$ As a result, I suggest that the construction of Article 297(1) favoured by the Tribunal in the Chagos Award should now have priority over the orthodox reading of this provision. To this end, it is worth mentioning that, during the jurisdiction and admissibility hearing in the South China Sea Case, the Philippines revised the interpretation of the meaning and effect of Article 297(1) it had advanced in its Memorial to be consistent with the Chagos Award's construction of this provision. ${ }^{60}$ Moreover, in its Award on Jurisdiction and Admissibility in the South China Sea Case, the Arbitral Tribunal acknowledged that a new interpretation of Article 297(1) had been favoured in the Chagos Award. Specifically, it observed that:

'Article 297 could be understood as implicitly limiting the jurisdiction of courts and tribunals over disputes concerning sovereign rights and jurisdiction in the exclusive economic zone only to the cases specifically identified in that Article. The Tribunal notes that Article 297 has sometime been interpreted in this way, although the tribunal in Chagos Marine Protected Area recently declined to endorse this interpretation.' 61

While the South China Sea Tribunal did not expressly endorse this new interpretation, it was not required to make a finding on this point. In the circumstances, I suggest that this simple act of recognition represents a sufficient signal for a wider change in the interpretation of Article 297(1).

\section{Conclusion}

In the concluding paragraph of his essay on the Chagos Award, Talmon counsels that:

\footnotetext{
59 Venzke, ibid, 63-64.

60 South China Sea Case (Philippines/People's Republic of China) Award on Jurisdiction and Admissibility, 29 October 2015, [361].

61 ibid, [359].
} 
'Part XV courts and tribunals faced with attempts to stretch the scope of compulsory subject-matter jurisdiction under UNCLOS ever further should tread carefully when interpreting and applying the jurisdictional provisions in Part XV. The significance for States of the limits to compulsory jurisdiction consciously built into the Convention should not be underestimated.' ${ }^{\prime} 2$

It may be that Talmon's target here is the stretching of mandatory jurisdiction in such a way as to permit sovereignty disputes to be adjudicated or arbitrated by virtue of the arrangements contained in Part XV. In this respect, his fears may be well-founded. Nevertheless, at least with regard to the terms of Article 297, it is not at all clear from the available texts what the limits of mandatory jurisdiction should be. This conundrum brings us to the relationship between law and politics.

In endorsing a broad interpretation of mandatory jurisdiction in the context of interpreting Article 297 in its Award, the Chagos Tribunal was adopting a definite position on the fundamental relationship between law and politics in international relations and it is suggested that we should read its interpretation of Article 297(1) accordingly. As Koskenniemi reminds us, the traditional modes of inter-State dispute settlement presuppose that if State consent remains the precondition for justiciability then it is always possible for States to avoid dispute resolution procedures. ${ }^{63}$ The traditional modes of inter-State dispute resolution have undoubtedly been offset by UNCLOS's dispute settlement provisions by which each State party has accepted the principle of compulsory jurisdiction entailing binding decision in certain cases. Nevertheless, the traditional, or background, assumption of the need for State consent to be specifically established in relation to a particular dispute (or in a given situation) still informs the extent to which advance consent can be invoked to justify expansive

\footnotetext{
62 Talmon (n 4), 31.

63 Martti Koskenniemi, “'The Function of Law in the International Community”, 75 Years After' (2008) 79 BYIL 353, 358; Hersch Lauterpacht, The Function of Law in the International Community (OUP 1933, reissued 2011); and Patrick Capps, 'Lauterpacht's Method' (2012) 82 BYIL 248.
} 
readings of the interpretation and application of the compulsory procedures contained in Part XV.

This feature of classical international law would appear to be consistent with the claim that where the actions of States are unconstrained by positive international law in a given sphere then what remains is politics. ${ }^{64}$ However, in sharp contrast, Lauterpacht argued that international law's reach is pervasive and, specifically, he claimed that a presumption exists, which holds that courts and tribunals possess jurisdiction for the purpose of deciding concrete cases unless jurisdiction has been explicitly excluded by the governing international instrument in question. ${ }^{65}$ Lauterpacht asserted that jurisdiction arises in default of positive textual authorisation and this can be justified by reference to the international community's latent commitment to the development of the international rule of law. For example, he claimed that a dispute should not be treated as non-justiciable on the ground that it concerns a State's 'vital interests' (and the sovereign rights and jurisdiction exercisable by coastal States in the extended maritime zones clearly qualify as vital interests). ${ }^{66}$ Lauterpacht believed that States' fundamental rights were safe in the hands of international judiciary because he thought they understood the nature of these entitlements in cases of dispute. For him, judges and arbitrators could be relied upon to reach credible decisions based on sound interpretations of the relevant legal materials. ${ }^{67}$ Accordingly, if as Lauterpacht, Koskenniemi and Venzke would have us believe, international law is rooted in the interpretative practices of the legal profession then judges and arbitrators constitute the foundations of the international rule of law. Against this background, it is suggested

\footnotetext{
${ }^{64}$ This viewpoint was propounded by Hans Morganthau. See Martti Koskennimei, The Gentle Civilizer of Nations: The Rise and Fall of International Law 1870-1960 (CUP, 2001), ch 6.

65 Koskenniemi (n 63), 358-9. This approach is consistent with the broad conceptions of mandatory jurisdiction, discussed in section 2.2.2, above.

66 ibid, 360.

67 ibid, 362-3.
} 
that the contest about the correct interpretation of Article 297(1) demonstrates that the fundamental debate about the correct relationship between law and politics in international relations is still ongoing and that the progressive realisation of the international rule of law is far from assured. 